\title{
The Bidayuh People of Sarawak Borneo: Ritual and Ceremonies
}

\author{
Awang Azman Awang Pawi ${ }^{1}$ \& Chali Ungang ${ }^{2}$ \\ ${ }^{1}$ Associate Professor of Academy of Malay Studies, University of Malaya, 50603, Kuala \\ Lumpur, Malaysia.Email Id: awangazman@um.edu.my, awangazman@gmail.com. \\ ORCID ID: 00oo-0003-4939-2706 \\ ${ }^{2}$ Research Scholar of Academy of Malay Studies, University of Malaya, 50603, Kuala \\ Lumpur, Malaysia. Email Id: charlieungang@yahoo.com
}

\begin{abstract}
This study aims to analyse the role of rituals and ceremonies of the Bidayuh tribes in Sarawak Borneo as a way of life of the Bidayuh people. Therefore, the cultural history of the Bidayuh people as well as the function and influence to the entire community which becomes the pride and identity is analysed. The data were taken from the Bajo asal (traditional songs), girite Bidayuh damba (stories and legendary), and the exploration and preview of the authenticity of the role in the manifestation of the Bidayuh culture and tradition in the numerous villagers through dynamic modernization. The content analysis was used to identify the rituals and ceremonies of the ethnic group. With this regard, emic perspective approach was applied to the study of the description of Bidayuh ritual, focussing on the internal elements and their functions in the Bidayuh society area in Bau, Padawan, and Serian division of Sarawak. Among the findings of this community is how important it is to preserve their beliefs to make sure the management of paddy fields are always cared for and preserve abundant harvests, apart from the 'guardians' to safe keep the peace of the village. The function and preservation through the ritual and ceremonies as their weltanschauung, influences the peasant society in that area. The study is highlighted to ensure people that the existence of the ritual and ceremonies is still implemented in the modern era as a part of the ancient heritage in Borneo Island- Sarawak.
\end{abstract}

Keywords: ritual and ceremonial process, customs and traditions, Bidayuh culture, Sarawak Borneo

\section{Introduction}

The role of rituals and ceremonies of the Bidayuh tribes in Sarawak Borneo as the way of life of the Bidayuh people. Thus, the cultural history of the Bidayuh people as well as the function and influence of the entire community becomes their pride and identity. The Bidayuh traditional villages are situated mostly in remote areas. There has always been peace and harmony among the people. While all the residents did not have family ties, the spirit of brotherhood between members of the society has always been closely intertwined. Rituals and ceremonies have played an important role in bringing the traditional Bidayuh together and creating a harmonious atmosphere in the village (Rawen anak Rumbud:202, Nyawan Atok:2020).

The process of rituals and ceremonies among the Bidayuh people are often described as a reflection of its backwardness by western researchers and are disliked by the Bidayuh community because it describes that the Bidayuh community is a primitive society. Social change in Bidayuh society is fast and dynamic. The younger generation of Bidayuh does not

(C) AesthetixMS 2021. This Open Access article is published under a Creative Commons Attribution Non-Commercial 4.o International License (http://creativecommons.org/licenses/by-nc/4.o/), which permits non-commercial re-use, distribution, and reproduction in any medium, provided the original work is properly cited. For citation use the DOI. For commercial re-use, please contact editor@rupkatha.com. 
show interest and commitment to preserve the cultural heritage and treasures of the Bidayuh tradition contained in the process of rituals and ceremonies. This phenomenon is very worrying because its glory is leading to a dim current of development. Even conservation efforts are still receiving a cold response among the Bidayuh community itself (Ginos Lumpoi: 2017).

\section{Objective and Methodology}

Study on Bidayuh cultural and customary heritage is still lacking and this has prompted the researcher to conduct this study in the hope to bring better understanding among the international community of the Bidayuh culture that is manifested in the process of ritual and ceremonies. This study aims to review and examine the rituals of preservation of customs and traditions contained in traditional ceremonies and celebrations centred in the community of the Bidayuh village in the Bau, Padawan, and Serian division of Sarawak in the hopes of fulfilling the following objectives, the first is to describe the history of traditional Bidayuh culture, second is to evaluate the influence of the ritual and ceremonial process in moulding the life of the Bidayuh people, and the last is to summarize the function of the process of rituals and ceremonies for conservation.

This study is an ethnographic study. Qualitative methods are applied in this study with the main focus is primary and secondary research. Through primary research, the collection of data and information is through fieldwork. Interviews were conducted among informants in various villagers like Kampung Opar and Gumbang in Bau, Kampung Piching and Kampung Bantang in Serian, and Kampung Anah Rais in Padawan. However, in addition to fieldwork, researchers used the library research method, and interviews were also conducted to obtain additional information. Qualitative methods (Stephen D, 2012) examine social settings from an internal perspective and producing descriptions and analyses, rather than using numbers, to obtain meaning. Qualitative research has two dimensions: an interpretive perspective, which focuses on expressing participants' views, and a critical perspective, which is based on interpretive perspectives but also examines how strength is embedded in the social environment.

\section{Rituals and Worship}

Nais (1989) described the ritual process and ceremonies among the Bidayuh people as closely linked to worship of spirits and Tampa in the traditional Bidayuh community. According to him, "worship in traditional Bidayuh is to surrender to the more powerful for help and to avoid any disruption and disaster that may occur. For traditional Bidayuh it is a manifestation of willingness to do anything to please a more powerful force." In his writings, Howard (2003: 174) attributed the end goal of sacrifice is intended that the request to be granted the benefit of the inhabitants of the village is seen as the way of life in the traditional era. This ritual is unique not only among Bidayuh ethnic but is also occurs in the Borneo indigenous society and the whole Malay Archipelago (Awang Azman Awang Pawi, 2014). For example, among the Iban in Rajang bastin in the rural area in Sarawak, and Kadazan Dusun in Kadamaian Kota Belud, Sabah Borneo.

The traditional Bidayuh community believes in the existence of spirits that could harm them. Therefore, they have no choice but to comply with all the rules to avoid angering the spirits and their actions against them. These rules were later developed into customs observed strictly by the community. Rituals and ceremonies were practices in every Bidayuh village, beliefs, and practices of ancestors inherited from generation to generation and must be complied to avoid disaster. Religious ceremonies and rituals are held at each stage of life from 
birth to death. Ceremonies were adopted and performed according to procedures and rites, prescribed by babeh pirinteng.

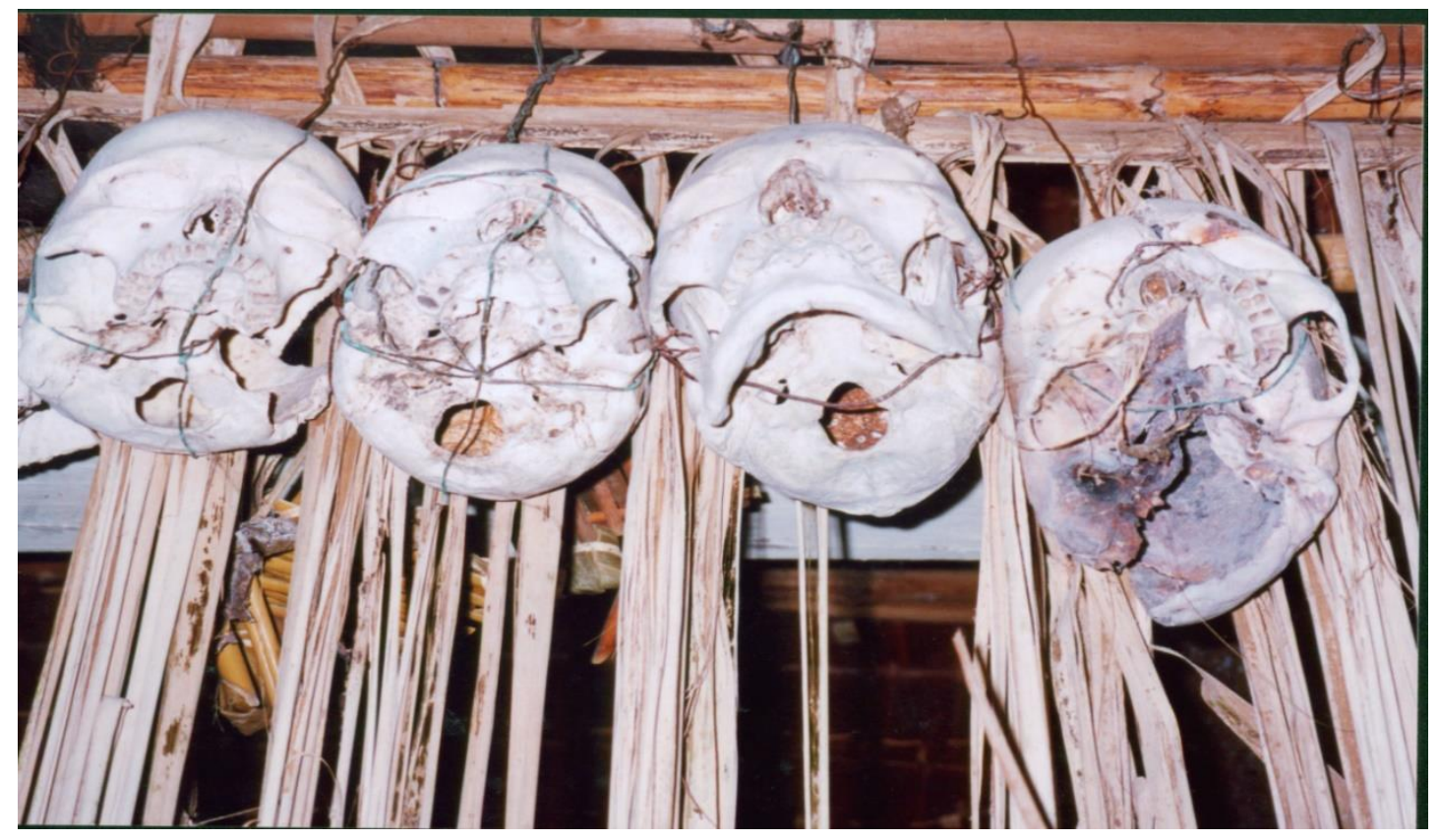

Photograph 1: The human skeleton is still kept in reserve residents in Kampung Opar Bau, neatly piled and hung in one corner of the baruk. One manifestation of that Bidayuh traditional treats the human skull as a symbol of heroism and masculinity that have inherited the spirit of continuity for the survival of the nation brave sharpshooter that continues to be strengthened in every human Bidayuh traditional era.

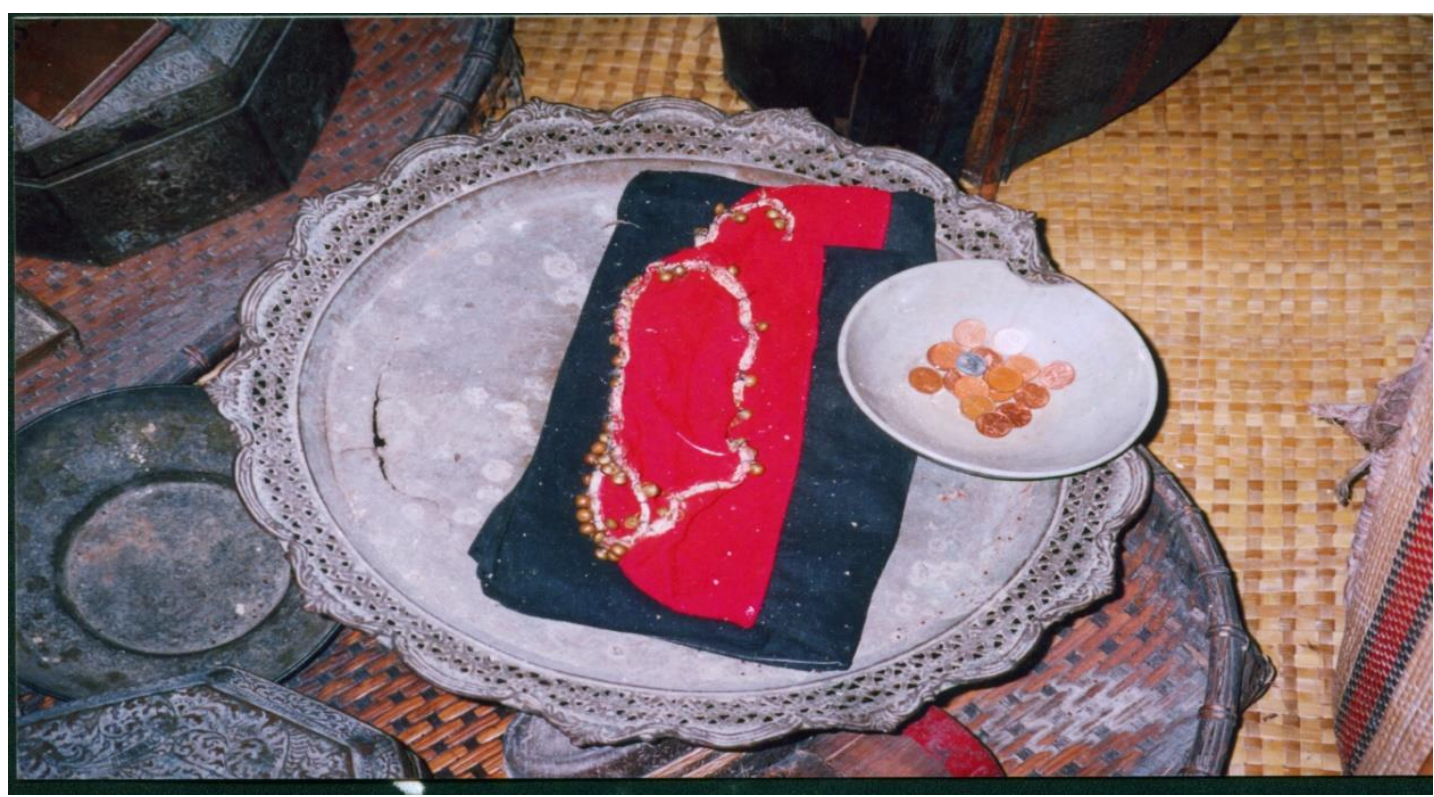

Photograph 2: Offerings to the spirits in baruk at Kampung Opar Bau.

\section{Passage for the spirit of rice}

Nirit dawu ampis tugat dawu sara diu

Nirit tangan ku dingu nyakit

Nyakit sampai sirungu kutu 
O diu kanchu pagai da

Ngapui badu linu

Tabanku nanju muat sulang

Tabanku nanju muat maoi

Tabanku nanju pinukap

Tabanku nanju pinabung

Tabanku nanju pimungo

Tabanku nanju pinyantang

Tabanku nanju Muat badu

Tabanku nanju muat sungkut

Tabanku nanju ati ngite

Tabanku nanju ati ngisok

Tabanku nanju muat bangas

Tabanku nanju muat bangas padi

Tabanku nanju bangas jagung

Tabanku nanju bangas simangku

Tabanku nanju bangas timun

Tabanku nanju bangas guttu

Tabanku nanju sumpah kireng

Tabanku nanju sumpah tami

Tabanku nanju sumpah babah

Tabanku nanju sumpah dayum

Tabanku nanju sumpah saringina

Nanyu nuh beda mandih

Beda nuh rampas narik awang

(Source: Rawin Anak Rumbud. Kampong Bantang 12 March 2020. Rites and Passage to appease the spirit of rice)

\section{Translation}

Take a leaf

To cure my disease

Curing all kinds of diseases

Oh hold the first ends

Turn glowing

For illuminates

Ghost the destroyer

Ghost the disease carrier

Take me to the shine of the hatred ghost

Take me to shine the phantom obstacle

Take me to shine the ghost blockers

Take me to shine a ghost bug

Take me to shine ghost of insects

Take me to shine ghost of termites

Take me to shine ghosts of caterpillars

Take me to light the devil disease 
Take me to shine rice disease

Take me to shine corn disease

Take me to shine watermelon disease

Take me to shine cucumber disease

Take me to shine spinach disease

Take me to shine the liars

Take me to shine a traitor oath

Take me to shine the pretenders

Take me to shine the oath

Let them perish

Let us run away from our rice

Before the ceremony is conducted, some preparation should be made, including preparing offerings to the rice fields. An elderly woman who knows the spell-like Rawin anak Rumbud would be called to the baruk in traditional Bidayuh costume. She would then place blowflies with some food offered to the spirit of paddy, accompanied by the sound of gongs to symbolize that the ritual ended.

Seven slices of cooked chicken livers

Seven slices of cooked pork liver

Seven stick bamboo cylinder containing cooked glutinous rice

One bowl of fish pickle

Seven slices of turmeric leaves

Seven slices of betel nuts

Seven stems of paddy shoot

One small knife blade

One black feather live chicken

Half yard of plain cloth in black color.

Table 1: List of items prepared for ritual proses and ceremonies to be presented to the rice spirit (Source: Interview with Ketua Gawai Nyawan Atok, 78 years old of Kampung Gumbang Bau.

Food needed for offerings is wrapped in leaves by the women. Foods that have been wrapped are put into a basket in black cloth. Then, they start moving to the baruk where the ceremony takes place, and then to the paddy fields nearby. In the paddy fields, the food would be left inside the sanggar. A black chicken would be slaughtered to end the ritual. Chicken blood would be sprinkled all along the path to the village. Symbolically, the chosen paddy field represents the whole region of paddy fields cultivated by the villagers.

\section{Ritual and offerings to the spirit of the human skulls}

Offerings to human skull ceremony referred to the Bidayuh as gawai baak, held in honour of the skull that has been obtained by warriors in the battle between villages in headhunting expeditions. The spirits of the skull would be invited to appease the spirits in their new home, which is the baruk. Some researchers like Bock associated it with a tendency to human being need and stated that;

The barbarous practice of head-hunting, as carried on by all the Dayaks tribes, not only in the independent territories but also in some parts of the tributary states, is part and parcel of their religious rites. Births and naming, marriages and burials, not to mention less important events, cannot be properly celebrated unless the heads of a few enemies, more or less, have been secured to grace the festivities or solemnities. (Bock, 1985:2:15) 
However, according to Walker (2002), during the reign of James Brooke, the practice of cutting head was no longer in existence, but the residents were allowed to celebrate skulls as trophies inherited from their ancestors. In later years, Bidayuh gradually began to lose interest in the ceremony. Referring to Nais (1988) stated that preparation of rituals and ceremonies must be prepared at least a year in advance. Concerning that, only men and women over the age of thirty years of age were permitted to organize this festival unless they were heroes or had taken part in the expedition where headhunting was carried out.

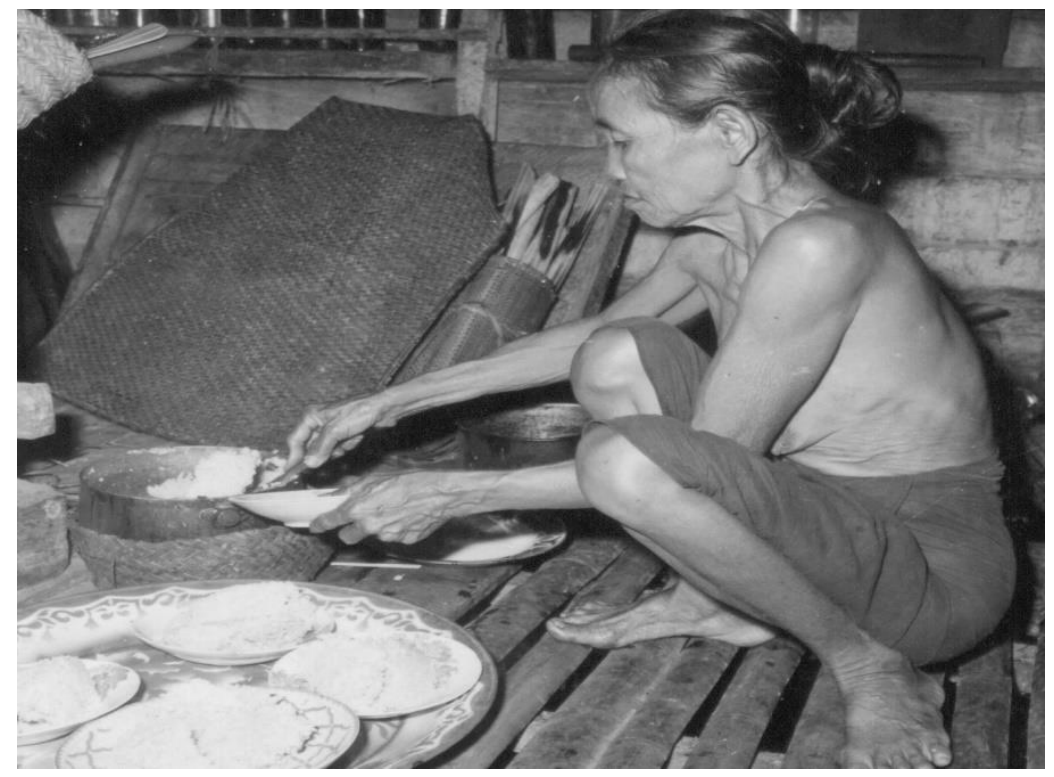

Photograph 3: Preparations of foods for skulls ceremonies in Kampung Mentu Tapu, Serian in 1954. (Source: Department of Sarawak Museum).

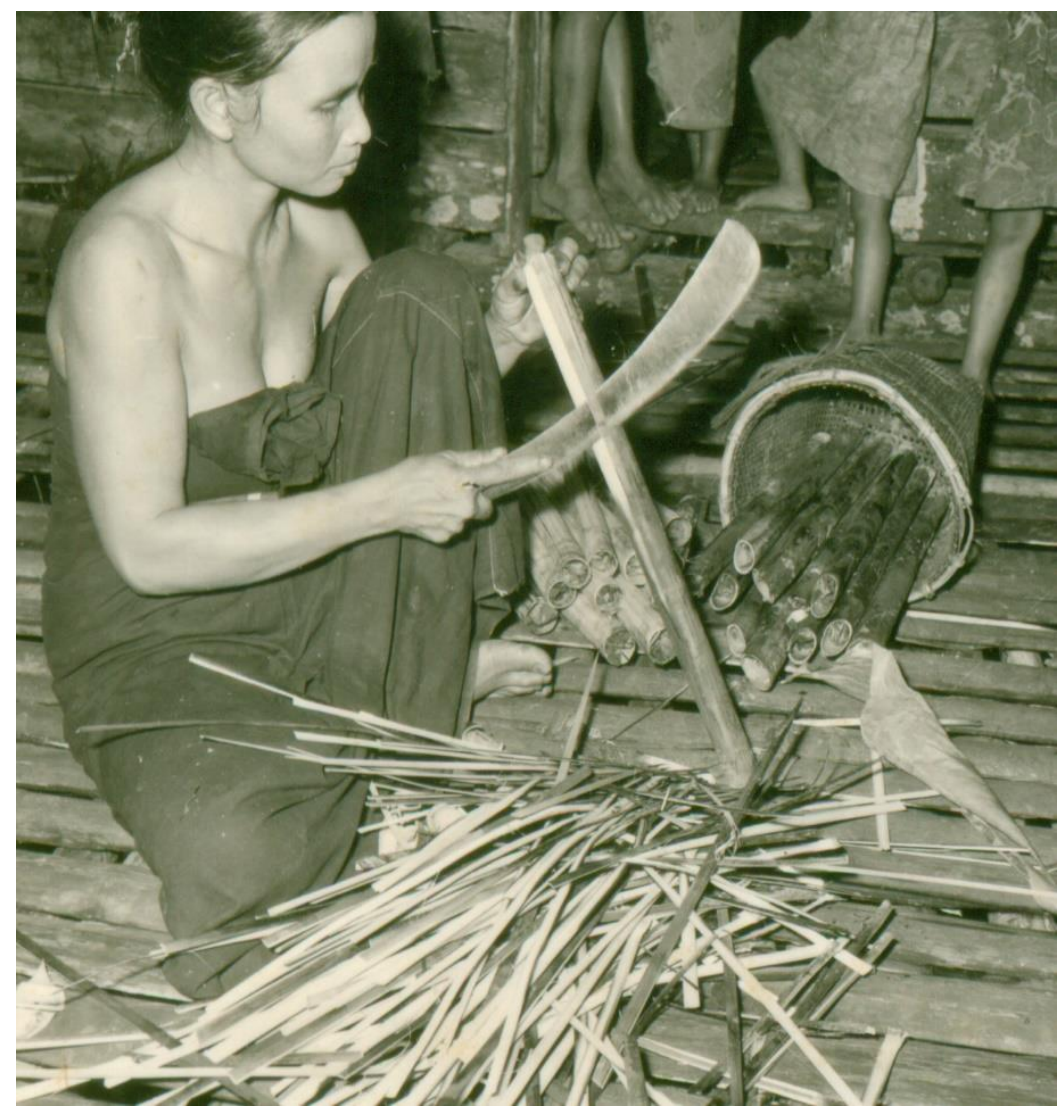

Photograph 4: Lemang (pangkang) prepared for the skull ceremony in Kampung Mentu Tapu, Serian on August 30, 1954 (Source: Department of Sarawak Museum). 


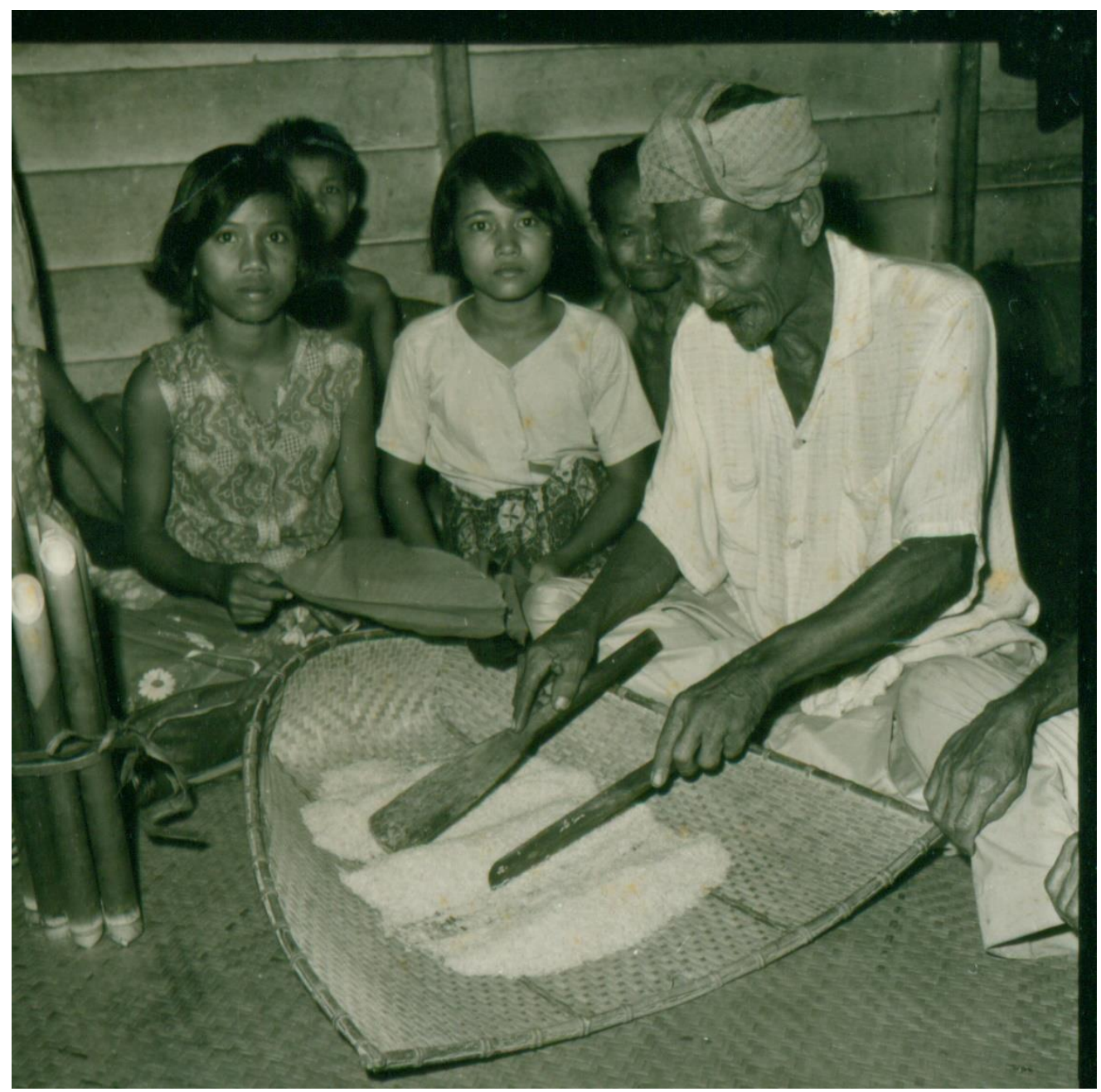

Photograph 5: An Elder preparing ceremonial offerings to the skull spirit Mentu Tapu on August 30, 1954. Photo Sarawak Museum Department. (Source: Department of Sarawak museum)

The skull offering ceremony would be held in stages. This happened for two reasons. The first is to enable the public to abstain from insufficient time, usually within two or three months. The second is to determine whether the skull spirit feels "happy" to stay in a new "place", namely the baruk, which is only known by the tua gawai through his interpretation. The types of food that should be provided is as follows;

1. Baram sinampur daya siyok da buru nan kirubung baak nyuhup

2. Baru kunyit nabur da sasah kirubung tanda bidingan

3. Sungkoi tungkus angkang kodog da sasah kirubung nan nuh maan

4. Sungkoi dog binisa minan omon bahai lalu binungkus minan dawu nan kirubung maan lalu supaya sien jani guna kampong

5. Kunyit odog numpuh lalu barut da dawe nan entamu kirunung lalu jaji bala kita da binua

6. Makko, rimu diput, dawe baid, bua bahai dangan gambit kodog da sasah nan kirubung maan.

7. Barak ambun dam oh masak kodog da sasah kirubung

8. Songkoi da buru diput ato pangkang 
9. Umbos ikan siluang da moh masak

10. Rukok dawe apung kodog da raang kirubung.

(Source: Interview with Pemancha Kane in Tebedu District Office 18 March 2019)

\section{Translation}

1. Rice wine mixed with chicken blood in bamboo as a thirst quencher for the skull.

2. Rice sprinkled on the side of the skull as a sign of blessing and friendship.

3. The rice is wrapped in betel leaves to be placed near the skull.

4. Arecanut juice is shared and placed near the skull as a sign that he was one of the villagers.

5. Pounded turmeric powder is added to preserve the skulls.

6. Tabaco, lime, slices of betel leaf, betel nuts, and Gambier were placed and arranged in order as part of food by the side of the skull.

7. Ripe bananas were placed by the sides as part of the supplementary food for the skulls.

8. Rice is stuffed inside a small bamboo or pangkang.

9. Packages containing cooked fish meat are wrapped with leaves.

10. Dried mangrove shoots infused in the jaws of the skull to be used as a cigarette.

The villagers would get together inside the baruk with various dishes they had prepared, arranged, and placed accordingly, and then the nyarra session began. It is a tradition representing the spirit of togetherness in the Bidayuh community as practiced since the traditional era till today. The skull worshipping ceremony commences with several trays containing offerings. Trays that had been prepared with offerings would be paraded around the skulls in the centre point of the baruk, accompanied by graceful dancers in full traditional costumes to the beat of the gongs. Trays would be arranged in the following manner containing following things;

The first tray: seven cooked eggs to be presented to the spirit of the hills and mountains, through spirits skull.

The second tray: seven kinds of offerings served for Daya Guna spirit

The third tray: seven kinds of offerings served to the spirit of the human skulls found in baruk

The fourth tray: seven kinds of offerings to the spirit of the tree

The fifth tray seven different kinds of offerings to spirits of wild animals in the forest.

The six trays: seven different types of offerings to spirits of rivers to keep the fish in the river to multiply.

The seventh tray: seven different kinds of offerings to worship the spirit of the ancestors who have died. 
The eighth tray: contained four types of offerings designated presentation for the spirit of evil creatures. The spirits of the skull "asked" to inform the evil creatures to stay away from the villagers.

The ninth tray: contained seven different kinds of offerings for the spirit of the Honey bee. The spirits of skulls expected to make more beehives on the branches around the villages.

(Source: Interview with Robert Sulis Ridu research, Majlis Research Assistant in the Department of Customs of Sarawak Chief Minister. June 18, 2017).

The description above is a manifestation that the human skull kept by the Bidayuh tribes in the baruk were treated with honour and respect. The spirit of skull was served reverently with dignity and according to the highest level of conduct of worship in the Bidayuh community. Each dish was prepared with a similar purpose, namely to persuade the passion of the spirit for the protection and security in everyday life.

The traditional Bidayuh believed that life was characterized by the practice of faith healing. In animism, sickness is usually attributed to spirits, demons, ghouls, and ghosts. The usual method used by shaman to cure patients is to read out spells to banish evil spirits that plague the patient's body. In many cases, rituals and ceremonies must be conducted as rites and passages towards the healing process. Healing rituals involve incantations and spells that could negatively affect the spirits to get out of the patient's body or stay away from it until the patient recovers.

Therefore, Ginos Lumpoi, 78 years old, a famous shaman in Kampung Bantang Serian revealed that in the early days, to treat a male patient he would go to the baruk to meet the patient to identify the sickness. Typically, it would be held at a night on a full moon because the procedures applied involved occult believing to be more effective. Ginos said that when magic spells were read accordingly, the evil spirits that inhabited inside the patient would be driven away. For example, a spell to cure the possessed by a ghost is as follows;

Incantations to cure people possessed by ghosts.

Uhhhhhhhhhh ... hah ... uhhhhhhhhhh..hah

Kurrrrrrrrrrrrrrrrrrahhhhhhhhh ...

aba aba amu

Mandug amu amu ngirusak aku

Mandeg amu lalu buhu ngajah baut jaran

Mandeg amu dangan umo bateh dangan balik kaii mudip

Mandeg amu maber libintat mahap

Aku mog jinaga babeh

Babeh nyugon pimagah, pimasi, pingirindu

Nan nangkis, nan ngilawan

Kandam aku

Muhun masu sigatung beh

Ngiran aku

\section{Translation}

Oh haaaaa......

Kurrrrrrrrrrahhh

Not me.....

Not you

You are the destroyer

Hopeless creature on earth

You came in tears and returned breathless 
But my protector is great

You are weak

My protector will shield me

He give me strength to fight you......and your evils ways to make me sick

He flies from the skies to wipe you

\section{Incantation to cast out evil spirits from interfering with a person's well-being.}

Burrrrrrrrrrrrrrr

oh ... huh ...

oh ... huh

aku nganchak akam pisuhon

nanchak dog Babe pirinteng

akam pingilamat aku

akam jinju aku

akam bandir aku

bipakat pinyayung akam ngilamat aku'

bada pimagah akam babeh pirinteng.

\section{Translation}

Burrrrrrrrrr

Ohhh.....hahhh

Ohhh...hhaaa

I appeal to you to command

My protector the great

He is my protector

He is my saviour

He is my source of strength

He created a fortress to defend my spirit

He commands his soldiers to fall from the skies

He commands his soldiers to emerge from the ocean

He dominates the mountains, the valleys, and the moon

He commands strong winds and storms to cripple my enemies

He is great........my creature is great

Burrrrrrrrrrrrrrrrrrrr,ohhhhhhhhhhh.........hahhhhhhhhh

(Source: Ginos Lumpoi 65 years. Interview research on 12 September 2007 in Kampong Bantang, Serian).

Ginos added healing through a shaman was to be conducted by no ordinary person. The skills were passed by babeh sibayan who created this beautiful universe to carry out responsibility entrusted by the tampa to ensure the welfare and well-being of the villagers. To possess this knowledge, patience, dexterity, and skill, he must abide and comply with the taboos imposed. To ensure it remains effective, a ceremony of pisumpa has to be conducted. Failure to comply within the stipulated time, usually before the full moon, would lead to the shaman himself being possessed by these evil spirits. Rituals would only be effective if it is performed and steps for pisumpa or rituals of offering and ceremonies as follows.

1. collect all materials, magical oils and wood carved to symbolize faces of gods.

2. wrap all the materials with a red cloth

3. place the material in the sanggar 
4. then place the materials underneath the skulls in the baruk

5. The shaman sat facing the tools with his head tied with a red cloth, and spatter incense powder (kemayan) in a coconut shell containing lit charcoal.

6. The shaman spattered drops of blood of the black-feathered chicken on the tools he used

7. Conversation with the ghost commence as follows

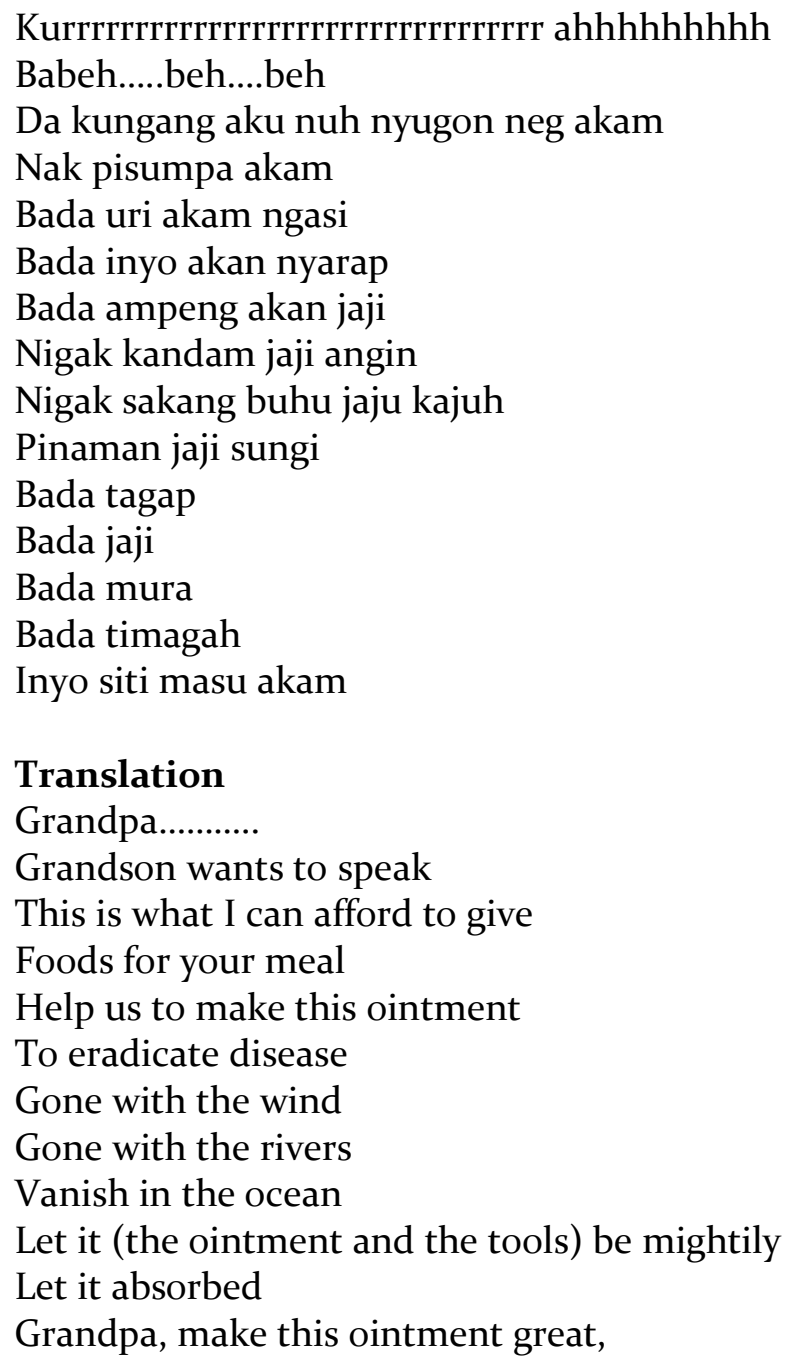

\section{Findings}

Human relationships with the supernatural are linked to the concept of nature in their environment. This belief has given them the confidence to move them to realize ideas related to the relationships of nature and supernatural powers engraved in their lives. Referring to Fortes, Meyer (1989, p. 229) stated this understanding illustrates that human beings want to make this world a meaningful place to live. Man seeks a principle of unification and survival from various experiences in life including practicing mystical beliefs and the worship of spirits.

This study discovered that the history of early settlements and the cosmology of the Bidayuh community who proved to adopt a culture of nomadic life to find a safe and marginalized environment from any threat. Their survival is closely related to the beliefs of animism, ritual ceremonies in the worship of the supernatural, and its influence is found in the jungles and caves have become practices that should not be side-lined. It is something that is 
born of action to avoid and stay away from any threats and intimidation as well as a solution to problems that are likely to keep themselves in misery and poverty. They depend on the tradition of bird watching as an omen of good and bad luck in their daily lives (Nais, 1996, p. 13)

Clifford Geertz (1973, p. 127) states that "ritual ceremonies in the belief of animism play an important role as a model that guides for human beings to manage life such as ways concerning the supernatural". This statement reinforces the opinion that the process of rituals and ceremonies are indeed the practices of worship of traditional beliefs as their way of life. This is done through interactions and behaviours centred on Bidayuh customs and traditions manifested in the ritual process and various ceremonies. The practice of this belief is presented through the worship of the spirits of the skull, the calling of the spirits of the dead, and the ceremony of casting off Muat Jirong as their god which they worship with mystical practices.

This opinion carries the meaning that the ritual offerings in the ceremonies are a form of worship of spirits for protection from disease attacks and the ability to enhance agricultural yields, easy sustenance while hunting, and so on, as found in the worship of skulls spirits. This phenomenon brings the interpretation that the ritual process and ceremonies were conducted to fulfill the purpose in some aspects of life that are closely related to the survival of Bidayuh.

The process of rituals in ceremonies serves as the premise of customs and worship as well as traditional celebrations related to the belief in tampa da ngundah dunya bidayuh (God who created the Bidayuh world). Apart from that, its main function is also closely related to the ceremony of seeking protection from enemy attacks, wild animals and catastrophes from spirits, and the emergence of ghosts. This is a manifestation that the ritual process and ceremonies have succeeded in shaping the life of the Bidayuh tribe through traditional worship rituals, ceremonies, and celebrations that are the traditional belief of the Bidayuh community.

\section{Conclusion}

Based on the findings, several conclusions are presented to discuss the purpose and objectives of the study. The first objective of the study which aims to describe the cultural history of Bidayuh of its ritual process, ceremonies, and worship have been achieved by exploring several events and rituals and worship ceremonies participated by researchers in Kampung Gumbang, Kampung Opar, and Kampung Pichin, all are Bidayuh traditional village which embraced close cultural and traditional practice yet considered fast advancing villages in developments among the Bidayuh community.

The Bidayuh community voiced that the ritual process and traditional ceremonies as a social and festive event that needs to be expanded in its role. This phenomenon is evident in several villages like Kampung Gumbang in Bau, Kampung Tree in Serian, and Kampung Anah Rais in Padawan. Through the findings of the study, it is concluded that the Bidayuh people have the same enemy, the same land, the same source of energy, the same customs, the same rules, and the same beliefs. This is the factor that forges and strengthens their relationship as a society that gives birth to a similar Bidayuh group and has similarities that allow all the rules and social norms in the Bidayuh community to be easily understood and followed. This shows the important rituals and ceremonies as a very important social institution in planning logistics in the village defence movement and the defensive fortifications of a Bidayuh village from any evil attacks and supernatural power interference. The daily life of the Bidayuh community depends on tampa riyuh, tampa pidadeg, and also the address of the bird. Symbols of tampa pidadeg (protective spirits) have been featured and paraded in several traditional Bidayuh festivals and celebrations to bring a picture of the situation faced by the traditional Bidayuh community, how important it is to preserve these spirits that help in making paddy fields always cared for and preserved abundant harvests, apart from the 'guardians' to the peace of the village. 
Through the discussion and findings of the study, it is concluded that the ritual process and ceremonies among the Bidayuh people need to be intensified to meet the social needs in the era of modernization. Its traditional role needs to be revived to be adapted to the tastes, techniques, and soul of the current generation. This effort will ensure the continuity of its role as a Bidayuh culture and tradition. Therefore, concrete and meaningful immediate steps need to be planned and action taken so that research and studies to be conducted on its greatness can be restored and revived. In conclusion, the findings of this study are done as a platform to provide space to attract the interest of various parties to give attention and opportunity to explore Bidayuh culture in depth, and hopefully will continue through new research as well as open space for discoveries involving culture to this precious heritage has not been swallowed up by time.

\section{Acknowledgement}

This study was supported by GAoog-2020 Socio-culture of the Bidayuh Ethnic, Sarawak Borneo Grant. Thank you to the Yayasan Sarawak and Research and Innovation Centre, Universiti Malaya (RIMC, UM) for the financial supports.

\section{References}

Ah Luk Chung, Rev. (1921). A Role of The Origin of The Land Dayak Villages of Sentah and Quop. The Sarawak Museum Journal.Vol1, No.2. Kuching: Sarawak Government Press.

Aman, Minchin, Michael. (1989). The Origin of Dayak Bidayuh or The History of Dayak Bidayuh. The Sarawak Museum Journal. Special Issue, Vol XL.No.61. Part II. Kuching: Sarawak Government Press.

Amir, Jeniri \& Azman, Awang. (2001). Kaul. Satu Interpretasi Sosiobudaya. Kuching, Sarawak: Massa Kasturi Management.

Anglican Mission In Sarawak. (1926). Annual Report and Pictorial Review For 1925. Kuching: Sarawak Government Press.

Awang Azman Awang Pawi. Ed.. (2014). Wajah Melayu Sarawak: Rampaian Ilmu Budaya. Kota Samarahan: Universiti Malaysia Sarawak (UNIMAS).

Barieng S. \& Bamfylde, C.A. (1909). A History of Sarawak Under Its Two White Rajah. London: Henry Southern \& Company Publications.

Bock, Carl. (1985). Bock, Charles. Farm E Settlement of The Sarawak Natives. The Sarawak Museum Journal. Vol. XXXI. Special Issue. No.3. Kuching: Sarawak Government Press.

Boyle, Frederick. (1984). Adventure Among the Dyaks of Borneo. Kuala Lumpur. Malaysia: Antara Book Company.

Britton. D G. (1969). The Forging of a Ritual Knife by Land Dayaks. The Sarawak Museum Journal. Kuching: Sarawak Government Press.

Chua, Liana C.L. (2007). Objects of Culture: Constituting Bidayuh-ness in Sarawak, East Malaysia. Ph.D. Dissertation. Cambridge University: London.

Department of Sarawak Museum Resources Centre.

Geddes, W.R. (1954). The Land Dayaks of Sarawak. Colonial Research Studies.No.14, London: Her Majesty's Stationary Office.

Geddes, W.R. (1957). Nine Dayak Nights. London: Oxford University Press.

Geertz, Clifford. (1973). The Interpretation of Culture. New York: Basic Book. 
Hewitt, John. (1961). The First Land Dayaks. The Sarawak Museum Journal.Vol.1o, No.17: The Sarawak Government Press.

Howard, Peter. (2003). Heritage: Management, Interpretation, Identity. Great Britain: MPG Books Lt

Howell, William. (1963). The Sea Dyaks and Other Races of Sarawak. Kuala Lumpur: Dewan Bahasa dan Pustaka.

Lapan, Stephen D. (2012) Qualitative research: an introduction to methods and designs. San Francisco USA: John Wiley \& Sons, Inc.

Nais, William. (1992). The Study of Dayak Bidayuh Occult Arts of Divination. Kuching: Sarawak Literature Society. Lee Ming Press Sdn. Bhd.

Noeb, Jonas. (1990). The Bidayuh Head House. The Sarawak Museum Journal.Vol. XL. No.61. Part II. Kuching: Percetakan Nasional Malaysia Berhad.

Ridu, Robert Jacob. (1989). Customs, Traditions, and Practices of the Dayak Bidayuh and Their Culture. The Sarawak Museum Journal. Special Issue. No.4 Vol. XL. Kuching: Sarawak Government Printing Press.

Turner, Victor. (1997). The Ritual Process. Structure and Anti-Structure. Aldine Transaction Publishers: New Brunswick. London. UK

Walker, J.H.(2002). Power and Prowess: The Origins of Brooke Kingship in Sarawak. New York Routledge.

Woods. E.Robert. (1997). Tourism and the State Ethnic Options and Constructions of Otherness. Honolulu: University of Hawaii Press.

Yeti Maunati: (2004). Identitas Dayak. Modifikasi dan Politik Kebudayaan. Yogyakarta: Penerbitan LKIS.

Yong Leng, Lee. (1981). Penduduk dan Penempatan di Sarawak. Kuala Lumpur: Dewan Bahasa dan Pustaka. 